\title{
Reassessment of endemic angiosperm genera in India
}

\author{
Irwin S.J. ${ }^{\text {* }}$, Narasimhan D. ${ }^{2} \&$ G. Rekha ${ }^{3}$ \\ ${ }^{1}$ No. 76/1, Arul Garden, Sundarapuram, Coimbatore, Tamil Nadu - 641 024, India \\ ${ }^{2}$ No. 5, Santhana Lakshmi Street, Rajeswari Nagar, Selaiyur, Chennai, Tamil Nadu - 600 059, India \\ ${ }^{3}$ No. 2, Kandhasamy Muthaliyar Street, Vettaikaran Pudur, Pollachi, Coimbatore, Tamil Nadu - 642 129, India \\ `E-mail: sheebajirwin@gmail.com
}

\begin{abstract}
This paper reassesses the current status of endemic genera after about a decade. Earlier Irwin and Narasimhan (2011) reported 49 genera as endemic to India. Later, Singh et al. (2015) have reported 58 endemic genera for India. We, in this paper, based on extensive scrutiny of literature and online resources, report a total of 46 genera as endemic to the political boundary of India. An analysis of the phytogeographical distribution of these genera confirms our earlier inference, except for minor variations in numbers of endemic genera in Peninsular Indian and Himalayan regions. The life form analysis shows that nearly three fourth of the endemic genera are herbaceous which occur predominantly in wet evergreen and grassland vegetation. In spite of their endemic nature, IUCN assessment at the global level has not yet been done for most of the species of these genera even though this gap was mentioned a decade earlier by Irwin and Narasimhan (2011).
\end{abstract}

Keywords: Angiosperm, Conservation, Endemism, Threat Status.

\section{Introduction}

Endemism reflects the environmental and biological history of a region (Hobohm et al., 2014; Vanderplank, 2014; Veron et al., 2019). Across the globe, 36 regions have been recognized as Biodiversity Hotspots based on the richness of endemism and level of habitat degradation (Noss et al., 2015; CEPF, 2016). Of these, four regions, namely, Indo-Burma, Eastern Himalayas, Western Ghats - Sri Lanka and the Sundaland majorly or partly fall within the boundaries of India

Received: 09.02.2021; Revised \& Accepted: 23.08.2021

Published Online: 31.12.2021
(Mittermeier et al., 2011) and posses higher concentrations of endemic genera. Of the total 18,532 species of angiosperms documented in India, the current estimate shows that only 4303 (29\%) taxa are endemic (Singh et al., 2015; Singh et al., 2018). These endemic species show narrow ranges of distribution and are restricted to peninsular regions, mountain tops, islands and unique geographical areas like swamps and mangroves. The present paper is an updated assessment of the endemic genera of angiosperms in India after Irwin and Narasimhan (2011) and Singh et al. (2015).

\section{Materials and Methods}

The following literature was consulted to revisit the endemic status of angiosperm genera recorded from India: Cooke (1901-1908); Chatterjee (1939); Bor (1949, 1954, 1958, 1960); Shaw (1952); Clifford (1967); Ansari and Hemadri (1971); Rao (1972, 1979); Mukherjee and Constance (1974); Saldanha (1974); Sohmer (1976); Hong (1980); Chakraborti (1981); Clayton (1981); Nair et al. (1982, 1983); Panigrahi and Das (1983); Uniyal and Pal (1983); Chakrabarty and Rao (1984); Pandurangan et al. (1984); Bhat (1986); Mukherjee and Constance (1986); Rao and Chakrabarty (1986); Takhtajan (1986); Ahmedullah and Nayar (1987); Sreekumar and Shetty (1987); Deshpande et al. (1989); Eriksson (1990); Matthew (1991); Mill (1991); Mathew and Lakshminarasimhan (1994); Kumar (1995); Sarkar (1995); Uniyal (1995); ING (1996); Nayar (1996); Sharma et al. (1996); Kumar and Rasmussen (1997); Shivamurthy and Sadanand (1997); Yoganarasimhan 
et al. (1997); Rao (1998); Sreekumar and Coomar (1999); Ahmedullah (2000); Janarthanam et al. (2000); Singh et al. (2001); Yadav and Sardesai (2002); Fonseca and Janarthanam (2003); Sasidharan (2004); Daniel (2005); Govaerts (2005); Govaerts (2006); Nayar et al. (2006); Venu (2006); Balakrishnan and Chakrabarty (2007); Mitra and Mukherjee (2007); Rajkumar and Janarthanam (2007); Anderberg and Pandey (2008); Kabeer and Nair (2009); Karthikeyan et al. (2009); Govaerts et al. (2011); SNMNH (2011); USDA (2011); eFloras (2011); Irwin and Narasimhan (2011); Singh et al. (2015); Clayton et al. (2016); ILDIS (2018); Mabberley (2018); IPNI (2020); Tropicos (2020); POWO (2020).

Genera that were earlier considered endemic and now show extended distributions and genera that were segregated earlier and merged later with the parent/allied genera based on phylogenetic reassessments have been critically reviewed (Table 2 ). The current updated list of endemic genera is arranged based on phytogeographical regions (Table 3). Species of each endemic genus are provided with state level distributions and habitats (Table 3). Families of the endemic genera are organized as per APG IV classification (APG IV, 2016). The threat status assessed for the species of these genera is also indicated (Deshpande, 1987a, b, 1988; Mukherjee, 1988; Ahmedullah and Nayar, 1990; Nayar, 1996; IUCN, 2020).

\section{Results}

\section{Earlier analysis}

There are different estimates of endemic genera by different authors in the last three decades based on the available information on distribution and nomenclatural changes (Table 1).

The present assessment shows that out of the 58 endemic genera documented by Singh et al. (2015) and 49 endemic genera listed by Irwin and Narasimhan (2011) only 43 genera have retained their endemic status. Genera that
Table 1: Earlier estimates on the number of Indian endemic genera

\begin{tabular}{|l|l|c|}
\hline No. & Authors & No. of Genera \\
\hline 1 & Sarkar (1995) & 142 \\
\hline 2 & Nayar (1996) & 147 \\
\hline 3 & Ahmedullah (2000) & 140 \\
\hline 4 & Mitra and Mukherjee (2007) & 121 \\
\hline 5 & Irwin and Narasimhan (2011) & 49 \\
\hline 6 & Singh et al. (2015) & 58 \\
\hline
\end{tabular}

include Frerea Dalzell, Lamprachaenium Benth., Meteoromyrtus Gamble, Munrochloa M.Kumar \& Remesh, Nanothamnus Thomson, Odisha S.Misra, Paracaryopsis (Riedl) R.R.Mill, Polyzygus Dalzell, Pseudojacobaea (Hook.f.) R.Mathur and Seshagiria Ansari \& Hemadri have been merged with their parental genera. The genus Trilobachne Schenck ex Henrard and Willisia Warm. show extended distribution to Myanmar and Bangladesh. Similarly, Decalepis Wight \& Arn. has lost its endemic status due to the extended distribution of Decalepis khasiana (Kurz) Lonta ex Kambale, to Bangladesh, South China and Myanmar. Canscorinella Shahina \& Nampy, a genus erected by Shahina and Nampy (2014), is again merged with its parent genus Canscora Lam. (POWO 2020, http:// www.plantsoftheworldonline.org/).

Many studies reported that the genus Hardwickia Roxb. lost its endemic status due to its distribution in many parts of the world especially in Bangladesh. Discussions with experts from India and Bangladesh as well as a thorough literature survey (Kundu \& Schmidt, 2011; Mitra \& Mukherjee, 2014) confirm that the genus occurs in other parts of the world only under cultivation.

\section{Current estimates of endemic genera in India}

Our analysis shows that the endemic genera in India constitute only $1.5 \%$ (46 genera) of the total 
Table 2. Status of genera earlier considered endemic in India

\begin{tabular}{|c|c|c|c|}
\hline \begin{tabular}{l|} 
S. \\
No.
\end{tabular} & $\begin{array}{l}\text { Genera considered endemic } \\
\text { (Irwin \& Narasimhan, 2011; } \\
\text { Singh et al., 2015) }\end{array}$ & $\begin{array}{l}\text { Parent genus with which merged / } \\
\text { extended distribution }\end{array}$ & Source \\
\hline 1 & $\begin{array}{l}\text { Canscorinella Shahina \& Nampy } \\
\text { (Gentianaceae) }\end{array}$ & Canscora Lam. & POWO, 2020 \\
\hline 2 & Frerea Dalzell (Apocynaceae) & Boucerosia Wight \& Arn. & $\begin{array}{l}\text { Meve \& Liede, 2002; } \\
\text { POWO, } 2020\end{array}$ \\
\hline 3 & Lamprachaenium Benth. (Asteraceae) & Phyllocephalum Blume & Roskov et al., 2018 \\
\hline 4 & Meteoromyrtus Gamble (Myrtaceae) & Eugenia L. & Wilson \& Heslewood, 2016 \\
\hline 5 & $\begin{array}{l}\text { Munrochloa M.Kumar \& Remesh } \\
\text { (Poaceae) }\end{array}$ & $\begin{array}{l}\text { Pseudoxytenanthera Soderstr. } \\
\text { \& R.P.Ellis }\end{array}$ & $\begin{array}{l}\text { Govaerts, 2011; POWO, } \\
2020\end{array}$ \\
\hline 6 & Nanothamnus Thomson (Asteraceae) & Blumea DC. & $\begin{array}{l}\text { Anderberg \& Pandey, 2008; } \\
\text { Mabberley, } 2018\end{array}$ \\
\hline 7 & Odisha S.Misra (Orchidaceae) & Habenaria Willd. & $\begin{array}{l}\text { Govaerts, 2011; POWO, } \\
2020\end{array}$ \\
\hline 8 & $\begin{array}{l}\text { Paracaryopsis (Riedl) R.R.Mill } \\
\text { (Boraginaceae) }\end{array}$ & Adelocaryum Brand. & Mill, 2010; Mabberley, 2018 \\
\hline 9 & Polyzygus Dalzell (Apiaceae) & Pinda P.K.Mukh. \& Constance & Lekhak \& Yadav, 2012 \\
\hline 10 & $\begin{array}{l}\text { Pseudojacobaea (Hook.f.) R.Mathur } \\
\text { (Asteraceae) }\end{array}$ & Senecio L. & Roskov et al., 2018 \\
\hline 11 & $\begin{array}{l}\text { Seshagiria Ansari \& Hemadri } \\
\text { (Apocynaceae) }\end{array}$ & Cynanchum L. & $\begin{array}{l}\text { Khanum et al., 2016; } \\
\text { Mabberley, } 2018\end{array}$ \\
\hline \multicolumn{4}{|c|}{ GENERA WITH EXTENDED DISTRIBUTION } \\
\hline 12 & Decalepis Wight \& Arn. (Apocynaceae) & Bangladesh, South China \& Myanmar & $\begin{array}{l}\text { Kambale et al., 2016; } \\
\text { Mabberley, } 2018\end{array}$ \\
\hline 14 & $\begin{array}{l}\text { Trilobachne Schenck ex Henrard } \\
\text { (Poaceae) }\end{array}$ & Myanmar & $\begin{array}{l}\text { Clayton et al., 2006; POWO, } \\
2020\end{array}$ \\
\hline 15 & Willisia Warm. (Podostemaceae) & Bangladesh & POWO, 2020 \\
\hline
\end{tabular}

2991 genera of flowering plants in India. They comprised of 78 taxa (Table 3). $78 \%$ of the endemic genera (36 genera) are confined to Peninsular India, $12 \%$ to the Himalayan region and about $6 \%$ to Andaman and Nicobar Islands. The genus Bentinckia Berry ex Roxb. shows disjunct distribution in two major phytogeographical regions namely India (Western Ghats) and IndoMalesia (Nicobar). Most of the endemic genera occur predominantly in wet evergreen forests and in high altitude grasslands. Genera such as Deccania Tirveng., Helicanthes Danser and Nicobariodendron Vasudeva Rao \& Chakrab. are found to occur in dry deciduous forests.
The endemic genera of India are distributed in 25 families. Of these, Poaceae contributes to $56 \%$ of the endemic genera, followed by Apiaceae (16\%) and Acanthaceae (12\%). 16 families are represented by a single taxon. Endemic genera are dominated by herbaceous forms ( 60 herbs) followed by trees (14) and shrubs (4).

Habit: CS - climbing shrub; H - herb; S - shrub; ST - small tree; $\mathrm{T}$ - tree.

\section{Threat status of Indian endemic genera}

The majority of taxa of the Indian endemic genera are threatened primarily because of their restricted range of distribution. However, only eight taxa 
Table 3. Endemic angiosperm genera of India, with included species, habit, habitat, and distribution

\begin{tabular}{|c|c|c|c|c|}
\hline $\begin{array}{l}\text { S. } \\
\text { No. }\end{array}$ & Genera / Species (Family) & Habit & Habitat & Distribution \\
\hline \multicolumn{5}{|c|}{ HIMALAYA } \\
\hline \multirow[t]{2}{*}{1} & Brachycaulos Dikshit \& Panigrahi (Rosaceae) & & & \\
\hline & B. simplicifolius Dikshit \& Panigrahi & $\mathrm{H}$ & $\mathrm{EF}$ & SK \\
\hline \multirow[t]{2}{*}{2} & Ivanjohnstonia Kazmi (Boraginaceae) & & & \\
\hline & I. jaunsariensis Kazmi & $\mathrm{H}$ & $\mathrm{EF}$ & UK \\
\hline \multirow[t]{2}{*}{3} & Kashmiria D.Y.Hong (Plantaginaceae) & & & \\
\hline & K. himalaica (Hook.f.) D.Y.Hong & $\mathrm{H}$ & $\mathrm{EF}$ & $\mathrm{J} \& \mathrm{~K}, \mathrm{UK}$ \\
\hline \multirow[t]{2}{*}{4} & Parakaempferia A.S.Rao \& D.M.Verma (Zingiberaceae) & & & \\
\hline & P. synantha A.S.Rao \& D.M.Verma & $\mathrm{H}$ & $\mathrm{EF}$ & AS \\
\hline \multirow[t]{2}{*}{5} & Pseudodanthonia Bor \& C.E. Hubb.(Poaceae) & & & \\
\hline & P. himalaica (Hook.f.) Bor \& C.E. Hubb. & $\mathrm{H}$ & $\mathrm{EF}$ & UK \\
\hline \multirow[t]{4}{*}{6} & Stapletonia P.Singh, S.S.Dash \& P.Kumari (Poaceae) & & & \\
\hline & S. arunachalensis (H.B.Naithani) P.Singh, S.S.Dash \& P.Kumari & $\mathrm{H}$ & $\mathrm{EF}$ & ARP \\
\hline & S. rigoensis L.B.Singha, P.Niri \& R.Devi & $\mathrm{H}$ & $\mathrm{EF}$ & ARP \\
\hline & S. seshagiriania (R.B.Majumdar) H.B.Naithani & $\mathrm{H}$ & $\mathrm{EF}$ & ARP \\
\hline \multicolumn{5}{|c|}{ PENINSULAR INDIA } \\
\hline \multirow[t]{2}{*}{7} & Adenoon Dalzell (Asteraceae) & & & \\
\hline & A. indicum Dalzell & $\mathrm{H}$ & GL & WG of KA, KL, MH, TN \\
\hline \multirow[t]{2}{*}{8} & Aenhenrya Gopalan (Orchidaceae) & & & \\
\hline & A. rotundifolia (Blatt.) C.S.Kumar \& F.N.Rasm. & $\mathrm{H}$ & EF & WG of KL, TN \\
\hline \multirow[t]{2}{*}{9} & Agasthiyamalaia S.Rajkumar \& Janarth. (Clusiaceae) & & & \\
\hline & A. pauciflora (Bedd.) S.Rajkumar \& Janarth. & $\mathrm{T}$ & EF & WG of KL, TN \\
\hline \multirow[t]{3}{*}{10} & Anaphyllum Schott (Araceae) & & & \\
\hline & A. beddomei Engl. & $\mathrm{H}$ & EF & WG of KL, TN \\
\hline & A. wightii Schott & $\mathrm{H}$ & $\begin{array}{l}\mathrm{EF}, \\
\mathrm{MDF}\end{array}$ & WG of KL, TN \\
\hline \multirow[t]{4}{*}{11} & Bhidea Stapf ex Bor (Poaceae) & & & \\
\hline & B. borii Deshp., V.Prakash \& N.P.Singh & $\mathrm{H}$ & GL & WG of KA \\
\hline & B. burnsiana Bor & $\mathrm{H}$ & GL & WG of KA, KL, MH \\
\hline & B. fischeri Sreek. \& B.V.Shetty & $\mathrm{H}$ & GL & WG of KL, MH \\
\hline \multirow[t]{2}{*}{12} & Blepharistemma Wall. ex Benth. (Rhizophoraceae) & & & \\
\hline & B. membranifolium (Miq.) Ding Hou & ST & MDF & WG of KA, KL \\
\hline
\end{tabular}




\begin{tabular}{|c|c|c|c|c|}
\hline \multirow[t]{2}{*}{13} & Calacanthus T.Anderson ex Benth. \& Hook.f. (Acanthaceae) & & & \\
\hline & C. grandiflorus (Dalzell) Radlk. & S & GL & WG of GA, KA, KL, MH \\
\hline \multirow[t]{2}{*}{14} & Chandrasekharania V.J.Nair, V.S.Ramach. \& Sreek. (Poaceae) & & & \\
\hline & C. keralensis V.J.Nair, V.S.Ramach. \& Sreek. & $\mathrm{H}$ & GL & WG of KA, KL \\
\hline \multirow[t]{2}{*}{15} & Cynarospermum Vollesen (Acanthaceae) & & & \\
\hline & C. asperrimum (Nees) Vollesen & $\mathrm{H}$ & MDF & WG of GA, KA, MH \\
\hline \multirow[t]{2}{*}{16} & Danthonidium C.E.Hubb. (Poaceae) & & & \\
\hline & D. gammiei (Bhide) C.E.Hubb. & $\mathrm{H}$ & GL & WG of KA, KL, MH \\
\hline \multirow[t]{3}{*}{17} & Deccania Tirveng. (Rubiaceae) & & & \\
\hline & D. pubescens (Roth) Tirveng. var. pubescens & $\mathrm{T}$ & $\begin{array}{l}\text { DEF, } \\
\text { DDF }\end{array}$ & $\mathrm{AP}, \mathrm{TN}$ \\
\hline & $\begin{array}{l}\text { D. pubescens (Roth) Tirveng. var. candolleana (Wight \& Arn.) } \\
\text { Tirveng. }\end{array}$ & $\mathrm{T}$ & $\begin{array}{l}\text { DEF, } \\
\text { DDF }\end{array}$ & AP, KA, TN \\
\hline \multirow[t]{2}{*}{18} & Erinocarpus Nimmo ex J.Graham (Malvaceae) & $\mathrm{T}$ & & WG of MH, KA \\
\hline & E. nimmonii J.Graham & & $\begin{array}{l}\text { MDF, } \\
\text { DDF }\end{array}$ & \\
\hline \multirow[t]{17}{*}{19} & Glyphochloa Clayton (Poaceae) & & & \\
\hline & G. acuminata (Hack.) Clayton var. acuminata & $\mathrm{H}$ & GL & WG of KA, KL, MH, TN \\
\hline & G. acuminata (Hack.) Clayton var. stocksii (Hook.f.) Clayton & $\mathrm{H}$ & GL & WG of $\mathrm{MH}$ \\
\hline & G. acuminata (Hack.) Clayton var. woodrowii (Bor) Clayton & $\mathrm{H}$ & GL & WG of MH \\
\hline & G. bombaiensis (Bor) Gosavi, S.R.Yadav, Praveen Karanth \& Survesw. & $\mathrm{H}$ & GL & WG of KA \\
\hline & G. divergens (Hack.) Clayton var. divergens & $\mathrm{H}$ & GL & WG of KA, KL \\
\hline & G. divergens (Hack.) Clayton var. hirsuta (C.E.C.Fisch.) Clayton & $\mathrm{H}$ & GL & WG of KA \\
\hline & G. forficulata (C.E.C.Fisch.) Clayton & $\mathrm{H}$ & GL & WG of KA, KL, MH, TN \\
\hline & G. goaensis (R.S.Rao \& Hemadri) Clayton & $\mathrm{H}$ & GL & WG of GA \\
\hline & G. henryi Janarth., V.C.Joshi \& S.Rajkumar & $\mathrm{H}$ & GL & WG of GA \\
\hline & G. maharashtraensis Potdar \& S.R.Yadav & $\mathrm{H}$ & GL & WG of MH \\
\hline & G. maharashtraensis var. hirsuta Potdar \& S.R.Yadav & $\mathrm{H}$ & GL & WG of MH \\
\hline & G. mysorensis (S.K.Jain \& Hemadri) Clayton & $\mathrm{H}$ & GL & WG of KA \\
\hline & G. ratnagirica (Kulkarni \& Hemadri) Clayton & $\mathrm{H}$ & GL & WG of MH \\
\hline & G. santapaui (S.K.Jain \& Deshp.) Clayton & $\mathrm{H}$ & GL & WG of MH \\
\hline & G. talbotii (Hook.f.) Clayton & $\mathrm{H}$ & GL & WG of MH \\
\hline & G. veldkampii M.A.Fonseca \& Janarth. & $\mathrm{H}$ & GL & WG of GA \\
\hline \multirow[t]{2}{*}{20} & Hardwickia Roxb. (Fabaceae) & & & \\
\hline & Hardwickia binata Roxb. & $\mathrm{T}$ & DDF & WG \& EG \\
\hline
\end{tabular}




\begin{tabular}{|c|c|c|c|c|}
\hline \multirow[t]{5}{*}{21} & Haplanthodes Kuntze (Acanthaceae) & & & \\
\hline & H. plumosa (T.Anderson) Panigrahi \& G.C.Das & $\mathrm{H}$ & MDF & WG of $\mathrm{MH}$ \\
\hline & H. tentaculatus (L.) R.B.Majumdar & $\mathrm{H}$ & MDF & WG of $\mathrm{GJ}, \mathrm{MH}$ \\
\hline & H. tentaculata var. neilgherryensis (Wight) J.R.I. Wood & $\mathrm{H}$ & MDF & WG of KA, KL \\
\hline & H. verticillatus (Roxb.) R.B.Majumdar & $\mathrm{H}$ & MDF & WG of KA, MH \\
\hline \multirow[t]{2}{*}{22} & Haplothismia Airy Shaw (Burmanniaceae) & & & \\
\hline & H. exannulata Airy Shaw & $\mathrm{H}$ & $\mathrm{EF}$ & WG of KL \\
\hline \multirow[t]{2}{*}{23} & Helicanthes Danser (Loranthaceae) & & & \\
\hline & H. elastica (Desr.) Danser & S & $\begin{array}{l}\mathrm{EF}, \\
\mathrm{MDF} / \\
\mathrm{P}\end{array}$ & WG of KA, MH \\
\hline \multirow[t]{3}{*}{24} & Hubbardia Bor (Poaceae) & & & \\
\hline & H. heptaneuron Bor & $\mathrm{H}$ & $\begin{array}{l}\text { MRL } \\
\text { in } \\
\text { MDF }\end{array}$ & WG of $\mathrm{MH}$ \\
\hline & H. diandra Chandore, Gosavi \& S.R.Yadav & $\mathrm{H}$ & $\begin{array}{l}\text { MRL } \\
\text { in SEF }\end{array}$ & WG of KA, MH \\
\hline \multirow[t]{2}{*}{25} & Indobanalia A.N.Henry \& B.Roy (Amaranthaceae) & & & \\
\hline & I. thyrsiflora (Moq.) A.N.Henry \& B.Roy & $\mathrm{H}$ & $\mathrm{EF}$ & WG of KA, KL, TN \\
\hline \multirow[t]{2}{*}{26} & Indopoa Bor (Poaceae) & & & \\
\hline & I. paupercula (Stapf) Bor ex Ramamoorthy & $\mathrm{H}$ & R/T/W & WG of KA, KL, MH \\
\hline \multirow[t]{2}{*}{27} & Jerdonia Wight (Gesneriaceae) & & & \\
\hline & J. indica Wight & $\mathrm{H}$ & $\mathrm{EF}$ & WG of KA, KL, TN \\
\hline \multirow[t]{2}{*}{28} & Karnataka P.K.Mukh. \& Constance (Apiaceae) & & & \\
\hline & K. benthamii (C.B.Clarke) P.K.Mukh. \& Constance & $\mathrm{H}$ & $\mathrm{EF}$ & WG of KA \\
\hline \multirow[t]{2}{*}{29} & Leucoblepharis Arn. (Asteraceae) & & & \\
\hline & L. subsessilis Arn. & S & MDF & $\begin{array}{l}\text { WG of KA, MH, MP, TN } \\
\text { and EG of AP }\end{array}$ \\
\hline \multirow[t]{2}{*}{30} & Limnopoa C.E.Hubb. (Poaceae) & & & \\
\hline & L. meeboldii (C.E.C.Fisch.) C.E.Hubb. & $\mathrm{H}$ & WL & WG of KA, KL \\
\hline \multirow[t]{3}{*}{31} & Lophopogon Hack. (Poaceae) & & & \\
\hline & L. ingie Hook.f. & $\mathrm{H}$ & DL & $\mathrm{BI}$ \\
\hline & L. tridentatus (Roxb.) Hack. & $\mathrm{H}$ & $\begin{array}{l}\text { P-LA/ } \\
\text { DL }\end{array}$ & $\begin{array}{l}\text { AP, BI, GJ, KA, MP, MH, } \\
\text { TN }\end{array}$ \\
\hline \multirow[t]{3}{*}{32} & Nanooravia Kiran Raj \& Sivad.(Poaceae) & & & \\
\hline & N. santapaui (M.R.Almeida) Kiran Raj \& Sivad. & $\mathrm{H}$ & GL & WG of KA, KL \\
\hline & $\begin{array}{l}\text { N. kayyurense Shaju, Rajendraprasad, Rijuraj \& Ratheesh } \\
\text { Narayanan }\end{array}$ & $\mathrm{H}$ & WL & WG of KL \\
\hline
\end{tabular}




\begin{tabular}{|c|c|c|c|c|}
\hline \multirow[t]{2}{*}{33} & Otonephelium Radlk. (Sapindaceae) & & & \\
\hline & O. stipulaceum Radlk. & $\mathrm{T}$ & $\begin{array}{l}\mathrm{EF} \\
\mathrm{MDF}\end{array}$ & WG of KA, KL, TN \\
\hline \multirow[t]{2}{*}{34} & Pinda P.K.Mukh. \& Constance (Apiaceae) & & & \\
\hline & P. concanensis (Dalzell) P.K.Mukh. \& Constance & $\mathrm{H}$ & MDF & WG of MH \\
\hline \multirow[t]{2}{*}{35} & Poeciloneuron Bedd. (Pentaphylacaceae) & & & \\
\hline & P. indicum Bedd. & $\mathrm{T}$ & $\mathrm{EF}$ & WG of KA, KL, TN \\
\hline \multirow[t]{2}{*}{36} & Pogonachne Bor (Poaceae) & & & \\
\hline & P. racemosa Bor & $\mathrm{H}$ & SGWC & WG of MH \\
\hline \multirow[t]{2}{*}{37} & Sanjappa E.R.Souza \& M.V.Krishnaraj (Fabaceae) & & & \\
\hline & S. cynometroides (Bedd.) E.R.Souza \& M.V.Krishnaraj & S & $\mathrm{EF}, \mathrm{SEF}$ & WG of KL \\
\hline \multirow[t]{2}{*}{38} & Sivadasania N.Mohanan \& Pimenov (Apiaceae) & & & \\
\hline & $\begin{array}{l}\text { S. josephiana (Wadhwa \& H.J.Chowdhery) N.Mohanan } \\
\text { \& Pimenov }\end{array}$ & $\mathrm{H}$ & $\mathrm{EF}$ & WG of KL \\
\hline \multirow[t]{3}{*}{39} & Silentvalleya V.J.Nair, Sreek., Vajr. \& Bhargavan (Poaceae) & & & \\
\hline & S. nairii V.J.Nair, Sreek., Vajr. \& Bhargavan & $\mathrm{H}$ & HAG & WG of KL \\
\hline & S. chandwadensis Gosavi, B.R.Pawar \& S.R.Yadav & $\mathrm{H}$ & MDF & WG of MH \\
\hline \multirow[t]{4}{*}{40} & Smithsonia C.J.Saldanha (Orchidaceae) & & & \\
\hline & S. maculata (Dalzell) C.J.Saldanha & $\mathrm{H}$ & MDF & WG of KA, KL, TN \\
\hline & S. straminea C.J.Saldanha & $\mathrm{H}$ & $\mathrm{EF}$ & WG of KA, KL \\
\hline & S. viridiflora (Dalzell) C.J.Saldanha & $\mathrm{H}$ & $\mathrm{EF}$ & WG of KA, KL, MH \\
\hline \multirow[t]{2}{*}{41} & Triplopogon Bor (Poaceae) & & & \\
\hline & T. ramosissimus (Hack.) Bor & $\mathrm{H}$ & SPHF & WG of MH \\
\hline \multirow[t]{2}{*}{42} & Vanasushava P.K.Mukh. \& Constance (Apiaceae) & & & \\
\hline & V. pedata (Wight) P.K.Mukh. \& Constance & $\mathrm{H}$ & HAG & WG of KA, KL, TN \\
\hline \multicolumn{5}{|c|}{ ANDAMAN AND NICOBAR ISLANDS } \\
\hline \multirow[t]{2}{*}{43} & Nicobariodendron Vasudeva Rao \& Chakrab. (Celastraceae) & & & \\
\hline & N. sleumeri Vasudeva Rao \& Chakrab. & $\mathrm{T}$ & $\begin{array}{l}\mathrm{MDF} \\
\mathrm{EF}\end{array}$ & NI \\
\hline \multirow[t]{2}{*}{44} & Pseudodiplospora Deb (Rubiaceae) & & & \\
\hline & P. andamanica (N.P.Balakr. \& N.G.Nair) Deb & $\mathrm{T}$ & $\mathrm{EF}$ & AI \\
\hline \multirow[t]{3}{*}{45} & Sphyranthera Hook.f. (Euphorbiaceae) & & & \\
\hline & S. airyshawii Chakrab. \& Vasudeva Rao & $\mathrm{T}$ & $\begin{array}{l}\text { MDF, } \\
\text { EF }\end{array}$ & $\mathrm{A} \& \mathrm{NI}$ \\
\hline & S. lutescens (Kurz) Pax \& K.Hoffm. & $\mathrm{T}$ & LF & $\mathrm{A} \& \mathrm{NI}$ \\
\hline
\end{tabular}




\begin{tabular}{|c|c|c|c|c|}
\hline \multicolumn{5}{|c|}{ PENINSULAR INDIA AND NICOBAR ISLANDS } \\
\hline 46 & Bentinckia Berry ex Roxb. (Arecaceae) & & & \\
\hline & B. condapanna Berry ex Roxb. & $\mathrm{T}$ & $\mathrm{EF}$ & WG of KL, TN \\
\hline & B. nicobarica (Kurz) Becc. & $\mathrm{T}$ & $\mathrm{EF}$ & NI \\
\hline
\end{tabular}

Habitat: AQ - aquatic; DDF - dry deciduous forests; DDF/SI - dry deciduous forests/scrub jungle; DEF - dry evergreen forests; DL - dry localities; EF - evergreen forests; GL - grasslands; HAG - high altitude grasslands; LP - lateritic plateaus; DDF - dry deciduous forests; MDF - moist deciduous forests; P - LA/DL - plains to low altitude, RRS - rocks in running streams; R/TT/W - on rocks, tree trunks and on old walls; SGWC - slopes of the Ghats near water courses; SP - HF stony places in hill forests; WL - wetlands.

Distribution: A \& NI - Andaman \& Nicobar Islands; AP - Andhra Pradesh; ARP - Arunachal Pradesh; AS - Assam; BI Bihar; GA - Goa; GJ - Gujarat; J \& K - Jammu \& Kashmir; KA - Karnataka, KL - Kerala; MP - Madhya Pradesh; MH Maharashtra; NI - Nicobar Islands; SK - Sikkim; TN - Tamil Nadu; UK - Uttarakhand; WG - Western Ghats; EG Eastern Ghats.

have been assessed so far based on IUCN threat Categories and Criteria by International Union for Conservation of Nature and Natural Resources (IUCN, 2020). They are: Agasthiyamalaia pauciflora (Critically Endangered B1+ 2c), Glyphochloa santapaui (Vulnerable (D2), Hubbardia heptaneuron (Vulnerable (D2), Limnopoa meeboldii (Endangered B2ab(iii)), Parakaempferia synantha (Critically Endangered B2ab (iii)), Sanjappa cynometroides (Critically Endangered B1b (i, ii) + C1(a)), Bentinckia condapanna (Vulnerable A1c) and B. nicobarica (Endangered C2a).

The most recently erected genus Sanjappa (Critically Endangered B1b (i, ii) + C1(a)) has been assessed based on Souza et al., (2016). Some of the species of endemic genera such as Blepharistemma membranifolium, Erinocarpus nimmonii, Glyphochloa divergens and Glyphochloa talbotii, Haplothismia exannulata, Pinda concanensis, Pseudodiplospora andamanica, Sphyranthera airyshawii and Vanasushava pedata have been assessed by Mukherjee (1988), Ahmedullah and Nayar (1990), Nayar (1996) and Deshpande (1987a, b) but based on the earlier version 1.0 - 3.0 of IUCN Red List Categories and Criteria.

\section{Discussion}

\section{Life-forms of the endemic genera}

Angiosperms are predominantly represented by herbaceous life forms (Nie et al., 2016) and this very well corroborates also with the Indian endemic genera that consist of $76 \%$ of herbaceous taxa.
Studies on monospecific endemic taxa also confirm the dominance of herbaceous taxa (64\%) in Indian flowering plants (Rana \& Ranade, 2009). Trees form the next dominant life forms. Only four endemic genera namely Calacanthus, Helicanthes, Leucoblepharis and Sanjappa are shrubby forms that are distributed in peninsular India.

\section{Monospecific genera}

Monospecific genera that are restricted to small geographical areas have received more attention in recent years from biogeographers due to their morphological uniqueness. This isolation is an indication of their relict nature and they form key floristic elements of the region (Rana \& Ranade, 2009; Vanderplank et al., 2014). Of the total monospecific endemic genera recorded, $64.7 \%$ taxa are herbaceous. Five of the endemic genera reported from Indian Himalayas are monospecific. Seventytwo percent of the Peninsular Indian endemics are unispecific and are represented by herbaceous families such as Acanthaceae, Asteraceae Poaceae and Apiaceae. Arborescent monospecific endemic genera are mostly found restricted to Peninsular India. All the four monospecific endemic shrubs namely Calacanthus, Helicanthes, Leucoblepharis and Sanjappa occur in Western Ghats. In spite of its rich diversity of understory flora in Western Ghats, endemism among shrubs is very low (Krishnan \& Davidar, 2007). Similarly, among the eight monospecific endemic genera, four genera namely Agasthiyamalaia, Blepharistemma, Erinocarpus and Otonephelium are reported from the Western Ghats. 
Based on the evolutionary age of the families of these monospecific tree genera (Li et al., 2019) and the geological age of the region, the endemic tree genera of the Western Ghats may be considered as paleoendemic relicts. Nicobariodendron and Pseudodiplospora are the relict endemics reported from the Andaman \& Nicobar Islands. Geographically isolated regions like mountain peaks and Islands are known for relict endemic floras (Kruckeberg, 2002; Lopez et al., 2011).

\section{Endemic genera of the Indian Himalaya}

The Himalayan phytogeographic region is rich in species diversity and possesses a high degree of endemism in India (Nayar, 1996; Singh et al., 2015). Though there are different classifications of the Indian Himalayan region, this paper follows the subdivision of Nandy et al. (2006). The present analysis reports six genera as endemic to the Indian Himalaya. These endemic genera are distributed in Trans-Himalayan, Western Himalayan, Central Himalayan and Eastern Himalayan subdivisions. The genus Kashmiria is distributed in both TransHimalayan and Western Himalayan subdivisions. The western Himalayan endemic genera Ivanjohnstonia and Pseudodanthonia are reported from Uttarakhand, and the Eastern Himalayan genus Parakaempferia is reported from Arunachal Pradesh, Assam and Meghalaya. The eastern Himalayan genus Brachycaulos is restricted to Sikkim while the genus Stapletonia occurs only in Arunachal Pradesh.

\section{Endemic genera of Peninsular India}

Peninsular India, that includes the Western and Eastern Ghats, is rich in species diversity due to its varied rainfall, temperature, latitudinal and altitudinal gradients (Nayar, 1996). The hill tops of the Ghats harbour about $53 \%$ of the endemic species of the country (Singh et al., 2015). It is considered that most of the endemic species found in the hills of Peninsular India are paleoendemics (Ahmedullah \& Nayar, 1987; Nayar, 1996). Of the 36 endemic genera in Peninsular India, 33 are exclusively distributed in the Western Ghats. In addition, four genera are extending to adjacent areas of the Western Ghats: Leucoblepharis is distributed in the moist deciduous forest of the Western and Eastern Ghats, Deccania occurs in dry deciduous forests of the Eastern Ghats of Tamil Nadu and Andhra Pradesh, Hardwickia is distributed in dry deciduous forests of the Western and Eastern Ghats and Lophopogon is distributed in dry localities throughout Peninsular India. Poaceae are the dominant family in the Western Ghats (Arora, 1964; Parthasarathy, 1983; Nair \& Daniel, 1986; Venu, 1998) with the highest (11) generic endemism and are mostly concentrated in the states of Karnataka, Kerala and Maharashtra. About 64 of the genera of Poaceae have been reported from grasslands. Two genera (Limnopoa, Pogonachne) and one species (Nanooravia kayyurense) occur in wetland habitats. Highest endemic species (16 taxa) diversity is found in Glyphochloa which are restricted to lateritic plateaus of the northern Western Ghats. Six tree genera have been reported from Peninsular India, all of which occur in the Western Ghats. Most of the Peninsular Indian endemics (Agasthiyamalaia, Blepharistemma, Otonephelium, Poeciloneuron) are confined to southern and central Western Ghats and whereas, Erinocarpus is restricted to the central and northern Western Ghats.

\section{Endemic genera of the Andaman \& Nicobar Islands}

The present analysis shows that the number of endemic genera remains the same and only three genera are endemic to these islands which occur in moist deciduous to wet evergreen forests (Irwin \& Narasimhan, 2011).

\section{Disjunct distribution of Bentinckia species}

The only endemic palm genus Bentinckia has two species and shows disjunct distribution. Bentinckia condapanna is distributed in the southern Western Ghats while, B. nicobarica is distributed in the Nicobar Islands. This type of distribution is evolved due to vicariance. Stuessy et al. (1998) proved in 
Juan Fernandez Islands and Chile that two closely related endemic species evolved due to vicariance. However, a clear picture of the two species of Bentinckia may emerge only from molecular phylogenetic studies.

\section{Threat status and conservation}

The threat status for $70 \%$ of the taxa belonging to endemic genera of India is yet to be assessed. Of the 80 taxa belonging to these genera, only 18 taxa have been assessed. Among these, only eight genera namely Agasthiyamalaia (1 sp.), Bentinckia (2 spp.), Glyphochloa (1 sp.), Hubbardia (1 sp.), Lamprachaenium (1 sp.), Limnopoa (1 sp.) and Sanjappa (1 sp.) have been assessed based on the IUCN Criteria (version 3.1). Hence, there is a need to assess the status of rest of the taxa. A few taxa, whose status has been assessed using older IUCN versions, need to be reassessed as per the latest version of IUCN's Red List Categories and Criteria (IUCN, 2020). Narrow habitat, limited seed set, lower dispersal rate, overexploitation, specialized niche, and low genetic variability positions most of these endemic species to possibly become threatened (Ashton, 1981; Ahmedullah \& Nayar, 1987; Abeli, 2010; Kani, 2011).

Brachycaulos simplicifolius Dikshit \& Panigrahi, is known only by its type and has not been recollected since then (Singh \& Pusalkar, 2020). Hence, this needs to be considered as presumably extinct.

Isolated habitats such as islands show rangerestricted species and therefore, have high levels of endemism (Kiera et al., 2009; Veron et al., 2019). Species with limited geographic distribution will become more vulnerable when compared to other taxa (Nayar, 1980; Kani, 2011) and anthropogenic stress forces these population to easily get extinct (e.g. Rossi et al., 2009; Peters et al., 2015).

Conservation of plants is more cost-effective compared to conservation of other organisms such as invertebrates (Gordon et al., 2019). Among the estimated vascular plants $13 \%$ are known to be threatened (Barik et al., 2018). Priority for conservation should be given to threatened and endemic genera/species that are restricted to a particular ecological zone and it is wise to map these species using remote sensing (Raven, 1988; Chiarucci, 2019; Volis, 2019). It is seen that fragmentation of terrestrial biomes is affecting the survival rate of the rare plants. Failure in pollination and seed dispersal of these plants or fragmented populations will adversely affect the endemic species of an area (Lander et al., 2019). The survival rate of isolated fragments is very low when compared to connected fragments especially in the case of narrow endemic species (Matesanz et al., 2017). Continuous monitoring of these fragmented populations is required for better conservation and management (Kani, 2011; Chiarucci, 2019). Research/academic institutions, scientists, government agencies and voluntary organizations have to collaborate together and work to conserve these endemic taxa in India.

\section{Acknowledgements}

Authors thank Dr. M. Sanjappa for his efforts to get the details on Hardwickia binata from Herbarium Keepers of different countries to establish that the reports from these countries are only from the cultivation and not from native forests. Dr. C. Sathish Kumar, Dr. S. R. Yadav, Dr. M. K. Janarthanam, Dr. K. Karthigeyan and Dr. W. Arisdason for their help in providing literature. We thank Dr. G. Gnanasekaran, Assistant Professor, Department of Botany, Madras Christian College, Chennai, for going through the draft of the manuscript.

\section{Literature Cited}

ABELI T. 2010. Survival of small isolated plant populations: an integrated approach to evaluate population viability for future conservation actions. Scientifica Acta 4: 3-9.

AHMEDULLAH M. 2000. Endemism in the Indian Flora. In: SINGH N.P., SINGH D.K., HAJRA P.K. \& B.D. SHARMA (eds.), Flora of India, Introductory Volume 1. Part 2. Botanical Survey of India, Kolkata. pp. 246265.

AHMEDULLAH M. \& M.P. NAYAR 1987. Endemic Plants of the Indian Region. Volume 1. Peninsular India. Botanical Survey of India, Kolkata. 
AHMEDULLAH M. \& M.P. NAYAR 1990. Erinocarpus nimmonii J.Graham. In: NAYAR, M.P. \& A.R.K. SASTRY (eds.), Red Data Book of Indian Plants. Vol. 3. Botanical Survey of India, Kolkata. p. 257.

ANDERBERG A.A. \& A.K. PANDEY 2008. Nanothamnus sericeus Thomson, a derived species of Blumea. Compositae Newsletter 46: 8-19.

ANSARI M.Y. \& K. HEMADRI 1971. Seshagiria Ansari \& Hemadri - a new genus of Asclepiadaceae from Sahyadri Ranges, India. Indian Forester 97: 126-127.

APG IV (Angiosperm Phylogeny Group IV) [Bremer, B., Bremer, K., Chase, M.W., Fay, M.F., Reveal, J.L., Soltis, D.E., Soltis, P.S. \& P.F. Stevens (comp.)] 2016. An update of the Angiosperm Phylogeny Group classification for the orders and families of flowering plants: APG IV. Botanical Journal of the Linnean Society 181: 1-20. https://doi.org/10.1111/boj.12385

ARORA R.K. 1964. Phytogeographical notes on the humid tropical flora of India - World distribution and analysis of the woody dicotyledonous flora of Western Ghats and Assam. The Journal of Indian Botanical Society 43: 220-228.

ASHTON P.S. 1981. Techniques for the identification and conservation of threatened species in tropical forests. In: SYNGE H. (ed.), The biological aspects of rare plant conservation. Wiley Inter Science, New York. pp. 155-164.

BALAKRISHNAN N.P. \& T. CHAKRABARTY 2007. The family Euphorbiaceae in India. Bishen Singh Mahendra Pal Singh, Dehra Dun.

BARIK S.K., TIWARI O.N., ADHIKARI D., SINGH P.P., TIWARY R. \& S. BARUA 2018. Geographic distribution pattern of threatened plants of India and steps taken for their conservation. Current Science 114(3): 470-503. https://doi.org/10.18520/CS/V114/I03/470-503

BHAT K.G. 1986. Limnopoa meeboldii (Fischer) C.E. Hubb. (Poaceae) a new record for Karnataka. Indian Journal of Forestry 9: 275.

BOR N.L. 1949. Pogonachne Bor: a new genus of Indian grasses. Kew Bulletin 4: 176-178.

BOR N.L. 1954. Notes on Asiatic Grasses: XV. Triplopogon Bor, a new genus of Indian grasses. Kew Bulletin 9: 51-56.

BOR N.L. 1958. Notes on Asiatic Grasses: XXXII. Indopoa Bor, a new genus of Indian grasses. Kew Bulletin 13: 225-226.

BOR N.L. 1960. The grasses of Burma, Ceylon, India and Pakistan. Pergamon Press, London.

CEPF (Critical Ecosystem Partnership Fund) 2016. Annual Report. www.cepf.net/resources/documents/cepfimpact-report-2016
CHAKRABARTY T. \& V. RAO 1984. A new species of Sphyranthera (Euphorbiaceae) from North Andaman Island. Journal of Economic and Taxonomic Botany 5: 959961.

CHAKRABORTI S. 1981. A new species of Blepharistemma from Western Ghats of India. Indian Science Congress Association Proceedings 68: 69.

CHIARUCCI A. \& G. PIOVESAN 2019. Need for a global map of forest naturalness for a sustainable future. Conservation Biology 34(2): 368-372. https://doi.org/ 10.1111/cobi.13408

CHATTERJEE D. 1939. Studies on the endemic flora of India and Burma. Journal of the Asiatic Society of Bangladesh Science 5: 19-68.

CLAYTON W.D. 1981. Notes on the Tribe Andropogoneae (Gramineae). Kew Bulletin 35: 813-818.

CLAYTON W.D., VORONTSOVA M.S., HARMAN K.T. \& H. WILLIAMSON 2016. World Grass Species Synonymy database. The Board of Trustees of the Royal Botanic Gardens, Kew.

CLIFFORD H.T. 1967. A contribution to the leaf anatomy of Hubbardia heptaneuron Bor (Gramineae). Kew Bulletin. 21: 169-174.

COOKE T. 1901-1908. The Flora of the Presidency of Bombay. Volume $1 \& 2$. Taylor \& Franics, London.

CSIR, 1959. The Wealth of India, a dictionary of Indian raw materials and industrial products. Council of Scientific and Industrial Research, New Delhi.

DANIEL P. 2005. Flora of Kerala. Volume 1. Ranunculaceae - Connaraceae. Botanical Survey of India, Kolkata.

DESHPANDE U.R. 1987a. Glyphochloa divergens (Hack.) Clayton. In: NAYAR M.P. \& A.R.K. SASTRY (eds.), Red Data Book of Indian Plants. Volume 1. Botanical Survey of India, Kolkata. p. 301.

DESHPANDE U.R. 1987b. Glyphochloa talbotii (Hook.f.) Clayton. In: NAYAR M.P. \& A.R.K. SASTRY (eds.), Red Data Book of Indian Plants. Volume 1. Botanical Survey of India, Kolkata. p. 302.

DESHPANDE U.R. 1988. Glyphochloa santapaui (S.K.Jain \& U.Deshp.) Clayton. In: NAYAR M.P. \& A.R.K. SASTRY (eds.), Red Data Book of Indian Plants. Volume 2. Botanical Survey of India, Kolkata. p. 185.

DESHPANDE U.R., PRAKASH V. \& N.P. SINGH 1989. Bhidea borii, a new species of Poaceae from India. Current Science 58: 1094-1095.

DIXIT B.K. \& G. PANIGRAHI 1981. Brachycaulos (Rosaceœ), a new genus from India. Bulletin $d u$ Museum National d'Histoire Naturelle, Section B, Adansonia series 4, 3(1): 58.

EFLORAS 2011. Published on the Internet, http:// www.efloras.org by Missouri Botanical Garden, St. Louis, Missouri \& Harvard University Herbaria, Cambridge. 
ERIKSSON T. 1990. Reinstatement of the genus Leucoblepharis Arnott (Asteraceae: Heliantheae). Botanische Jahrbücher für Systematik 112: 167-191.

FONSECA M.A. \& M.K. JANARTHANAM 2003. A new species of Glyphochloa W.D. Clayton (Poaceae) from Goa, India. Rheedea 13: 35-38.

HOBOHM C., VANDERPLANK S.E., JANISOVA M., TANG C.Q., PILS G., WERGER M.J.A., TUCKER C.M., R. CLARK V., BARKER N.P., MA K., MOREIRA-MUNOZ A., DEPPE U., FRANCIOLI S., HUANG J., JANSEN J., OHSAWA M, NOROOZI J., SEQUEIRA M.P.S., BRUCHMANN I., YANG W. \& Y. YANG 2014. Endemism in Vascular Plants: synthesis. In: HOBOHM C. (ed.), Endemism in vascular plants. Springer Science, New York. p. 309-348

GORDON R.E., BUTT N., ROSNER-KATZ H., BINLEY D.A. \& J.R. BENNETT 2019. Relative costs of conserving threatened species across taxonomic groups. Conservation Biology 34(1): 276-281. https:// doi.org/10.1111/cobi.13382

GOVAERTS R. 2005. World Checklist of Myrtaceae. The Board of Trustees of the Royal Botanic Gardens, Kew. Available at: http://www.kew.org/wcsp

GOVAERTS R. 2006. World Checklist of Monocotyledons. The Board of Trustees of the Royal Botanic Gardens. Kew. Published on the Internet, http://www.kew.org/ wcsp/monocots

GOVAERTS R., RUHSAM M., ANDERSSON L., ROBBRECHT E., BRIDSON D.M., DAVIS A.P., SCHANZER I. \& B. SONKÉ 2011. World Checklist of Rubiaceae. The Board of Trustees of the Royal Botanic Gardens, Kew. Available at: http://apps.kew.org/wcsp

GRIN 2011. United States Department of Agriculture, Agricultural Research Service, Germplasm Resources Information Network - (GRIN) [Online Database] Available at: http://www.arsgrin.gov/cgi-bin/npgs/ html/taxgenform.pl

HONG D.Y. 1980. Kashmiria (Scrophulariaceae, Veroniceae), a new name for Falconeria Hook.f. from the Western Himalaya. Botaniska Notiser 133: 565-567.

ILDIS 2018. International Legume Database \& Information Service. Available at: http://www.ildis.org

ING 1996. The National Museum of Natural History, Smithsonian. Available at: http://botany.si.edu/ing/

IPNI 2020. The International Plant Name Index. http:// www.ipni.org

IRWIN S.J. \& D. NARASIMHAN 2011. Endemic genera of angiosperms in India: a review. Rheedea 21(1): 87-105.

IUCN 2020. The IUCN Red List of Threatened Species. Version 2020-1. https://www.iucnredlist.org

JANARTHANAM M.K., JOSHI V.C. \& S. RAJKUMAR 2000. Glyphochloa henryi, a new species of Poaceae from Goa, India. Rheedea 10: 99-102.
KABEER K.A.A. \& V.J. NAIR 2009. Flora of Tamil Nadu - grasses. Botanical Survey of India, Kolkata.

KAMBALE S.S., GHOLAVE A.R., BHATTACHARJEE A. \& S.R. YADAV. 2016. Typifications and validations of taxa in the genus Decalepis: an economically and ethnobotanically important genus of Gymnanthereae (Apocynaceae: Periplocoideae). Taxon 65(4): 875-877. https://doi.org/10.12705/654.14

KANI I. 2011. Rare and endemic species: why are they prone to extinction? Turkish Journal of Botany 35: 411-417.

KARTHIKEYAN S., SANJAPPA M. \& S. MOORTHY 2009. Flowering plants of India. Dicotyledons. Volume I. Acanthaceae - Avicenniaceae. Botanical Survey of India, Kolkata.

KHANUM R., SURVESWARAN S., MEVE U. \& S.L. SCHUMANN 2016. Cynanchum Apocynaceae: Asclepiadoideae): a pantropical Asclepiadoid genus revisited. Taxon 65(3): 467-486. https://doi.org/ $10.12705 / 653.3$

KIER G., KREFT H., LEE T.M., JETZ W., IBISCH P.L., NOWICKI C., MUTKE J. \& W. BARTHLOTT 2009. A global assessment of endemism and species richness across island and mainland regions. Proceedings of the National Academy of Sciences 106(23): 9322-9327. https:/ /doi.org/10.1073/pnas.0810306106

KRISHNAN R.M. \& P. DAVIDAR 2007. The shrubs of the Western Ghats (South India): floristics and status. Journal of Biogeography 23: 783-789. https://doi.org/ 10.1111/j.1365-2699.1996.tb00039.x

KRUCKEBERG, A. R. 2002. Geology and plant life: The effects of landforms and rock types on plants. University of Washington Press, London. P. 304.

KUMAR C.S. \& F.N. RASMUSSEN 1997. The reappearance of Odontochilus rotundifolius Blatter and its transfer to Aenhenrya Gopalan (Orchidaceae). Novon 7: 81-84.

KUMAR S. 1995. Subtribe 6. Plucheineae Cass. In: HAJRA, P.K., RAO, R.R., SINGH, D.K. \& B.P. UNIYAL (eds.), Flora of India. Volume 13. Botanical Survey of India, Kolkata. pp. 151-153.

KUNDU M. \& SCHMIDT L.H. 2011. Hardwickia binata Roxb. Seed Leaflet 152.

LANDER A.T., HARRIS A.S., CREMONA J.P. \& H.D. BOSHIER 2019. Impact of habitat loss and fragmentation on reproduction, dispersal and species persistence for an endangered Chilean tree. Conservation Genetics 20: 973-985. https://doi.org/10.1007/s10592019-01187-z

LEKHAK M.M. \& S.R. YADAV 2012. Herbaceous vegetation of threatened high altitude lateritic plateau ecosystems of Western Ghats, southwestern Maharashtra, India. Rheedea 22(2): 39-61. 
LI H.T., YI T.S., GAO L.M., MA P.F., ZHANG T., YANG J.B.,GITZENDANNER M.A., FRITSH PW., CALI J., LUO Y., WANG H., BANK M.V., ZHANG S.D., WANG Q.F., WANG J., ZHANG Z.R., FU C.N., YANG J., HOLLINGSWORTH P.M., CHASE M.W., SOLTIS D.E., SOLTIS P.S. \& D.Z. LI. 2019. Origin of angiosperms and the puzzle of the Jurassic gap. Nature plants 5: 461-470. http://doi.org/10.1038/s41477-0190421-0

LOPEZ P.J., ZHANG F.M, SUN H.Q, YING T.S. \& S. GE 2011. Centres of plant endemism in China: places for survival or for speciation? Journal of Biogeography 38(7): 1267-1280. https://doi.org/ 10.1111/j.13652699.2011.02504.x

MABBERLEY D.J. 2018. Mabberley's Plant-Book: a portable dictionary of plants, their classification and uses. Fourth Edition. Cambridge University Press, Cambridge.

MATESANZ S., TESO R.L.M., GARCÍA-FERNÁNDEZ, A. \& A. ESCUDERO 2017. Habitat fragmentation differentially affects genetic variation, phenotypic plasticity and survival in populations of a gypsum endemic. Frontiers in Plant Science 8: 843. https://doi.org/ 10.3389/fpls.2017.00843

MATHEW S.P. \& P. LAKSHMINARASIMHAN 1994. Notes on two endemic Euphorbiaceous taxa from Andaman-Nicobar Islands, India. Bulletin of Botanical Survey of India 33: 311-314.

MATTHEW K.M. 1991. Notes on the distribution of Bentinckia condapanna on the Palani Hills in Peninsular India. Principes 35: 139-141.

MEVE U. \& S. LIEDE 2002. A molecular phylogeny and generic rearrangement of the stapelioid Ceropegieae (Apocynaceae - Asclepiadoideae). Plant Systematics and Evolution 234: 171-209. https://doi.org/10.1007/s00606002-0220-2

MILL R.R. 1991. The generic position of C.B. Clarke's species of Paracaryum (Boraginaceae). Edinburgh Journal of Botany 48: 55-62. https://doi.org/doi:10.1017/ S0960428600003619

MILL R.R. 2010. A new species and synopsis of Adelocaryum (Boraginaceae - Cynoglosseae) with notes on Lindelofia and Brandella. Edinburgh Journal of Botany 67: 141-154. https://doi.org/10.1017/S0960428609990278

MITRA S. \& S.K. MUKHERJEE 2007. Reassessment and diversity of endemic angiospermic genera of India. Journal of Economic and Taxonomic Botany 31: 163-176.

MlTRA S. \& S.K. MUKHERJEE 2014. Census of endemic angiospermic taxa of West Bengal, India. Journal of Economic and Taxonomic Botany 38(2): 2050-9768.

MITTERMEIER R.A., TURNER W.R., LARSEN F.W., BROOKS T.M. \& C. GASCON 2011. Global biodiversity conservation: the critical role of hotspots.
In: ZACHOS F.E. \& J.C. HABEL (eds.), Biodiversity hotspots. Springer-Verlag, Berlin \& Heidelberg. https:// doi.org/10.1007/978-3-642-20992-51

MUKHERJEE P.K. 1988. Vanasushava pedata (Wight) P.K.Mukh. \& Constance. In: NAYAR, M.P. \& A.R.K. SASTRY (eds.), Red data book of Indian plants. Volume 2. Botanical Survey of India, Kolkata. p. 30.

MUKHERJEE P.K. \& L. CONSTANCE 1974. Vanasushava, an old South Indian umbellifer renamed. Kew Bulletin 29: 593-596.

MUKHERJEE P.K. \& L. CONSTANCE 1986. A new disposition of the South Indian Heracleum concanense Dalzell (Umbelliferae). Kew Bulletin 41: 223-229.

NAIR N.C. \& P. DANIEL 1986. The floristic diversity of the Western Ghats and its conservation: a Review. Proceedings of the Indian Academy of Sciences. (Plant Sciences) Supplement 3: 127-263.

NAIR V.J., RAMACHANDRAN V.S. \& P.V. SREEKUMAR 1982. Chandrasekharania: a new genus of Poaceae from Kerala, India. Proceedings of the Indian Academy of Sciences. (Plant Sciences) 91: 79-82.

NAIR V.J., SREEKUMAR P.V., VAJRAVELU E. \& P. BHARGAVAN 1983. Silentvalleya: a new genus of Poaceae from Kerala, India. Journal of the Bombay Natural History Society 79: 654-657.

NANDY S.N., DHYANI P.P. \& P.K. SAMAL 2006. Resource information database of the Indian Himalaya. ENVIS Monograph 3: 1-123.

NAYAR M.P. 1980. Endemic flora of Peninsular India and its significance. Bulletin of Botanical Survey of India 22: 12-23.

NAYAR M.P. 1996. Hot spots of endemic plants of India, Nepal and Bhutan. Tropical Botanic Garden and Research Institute, Thiruvananthapuram.

NAYAR T.S., BEEGAM A.R., MOHANAN N. \& G. RAJKUMAR 2006. Flowering plants of Kerala - a handbook. Tropical Botanic Garden and Research Institute, Thiruvananthapuram.

NIE Z.L., FUNK V.A., MENG Y.T., H.S. DENG \& J. WEN 2016. Recent assembly of the global herbaceous flora: evidence from the paper daisies (Asteraceae: Gnaphalieae). New Phytologist 209: 1795-1806. https:// doi.org/10.1111/nph.13740

NOSS R.F., PLATT W.J., SORRIE B.A., WEAKLEY A.S., MEANS B.M., COSTANZA J.C. \& R.K. PEET 2015. How global biodiversity hotspots may go unrecognized: lessons from the North American coastal plain. Diversity and Distributions 21: 236-244. https://doi.org/10.1111/ ddi. 12278 
PANDURANGAN A.G., RAMACHANDRAN V.S. \& N.C. NAIR 1984. A note on new distribution and undescribed fruits of the rare plant Meteoromyrtus wynaadensis (Bedd.) Gamble (Myrtaceae) Kerala, India. Journal of Economic and Taxonomic Botany 5: 1185-1188.

PANIGRAHI G. \& G.C. DAS 1983. A revision of Haplanthodes O.Kuntze (Acanthaceae). Bulletin of Botanical Survey of India 23: 197-203.

PARTHASARTHY N. 1983. A phytogeographic analysis of the flora of Kalakad Reserve Forest, Western Ghats. The Journal of Indian Botanical Society 67: 342-346.

PETERS H., O'LEARY B.C., HAWKINS J.P. \& C.M. ROBERTS 2015. Identifying species at extinction risk using global models of anthropogenic impact. Global Change Biology 21(2): 618-628. https://doi.org/10.1111/ gcb.12749

POWO (Plants of the world online), 2020. Available at: http:// www.Plantsoftheworldonline.org.

RAJKUMAR S. \& M.K. JANARTHANAM 2007. Agasthiyamalaia (Clusiaceae), a new genus for Poeciloneuron pauciflorum, an endemic and endangered tree of Western Ghats, India. Journal of the Botanical Research Institute of Texas 1(1): 129-133. http:// www.jstor.org/stable/41971401

RANA T.S. \& S.A. RANADE 2009. The enigma of monotypic taxa and their taxonomic implications. Current Science 96: 219-229.

RAO A.N. 1998. India arunachalensis Nageswara Rao (Orchidaceae) - a new genus and species from Arunachal Pradesh, India. Journal of Economic and Taxonomic Botany 22: 701-703.

RAO M.K.V. \& T. CHAKRABARTY 1986. Nicobariodendron Vasud. \& T.Chakrab. (Celastraceae): a new genus from the Nicobar Islands, India. Journal of Economic and Taxonomic Botany 7: 513-516.

RAVEN P.H. 1988. Tropical floristics tomorrow. Taxon 37: 549-560. https://doi.org/10.2307/1221098

ROSKOV Y., ABUCAY L., ORRELL T., NICOLSON D., BAILLY N., KIRK P.M., BOURGOIN T., DEWALT R.E., DECOCK W., DE WEVER A., NIEUKERKEN E. VAN, ZARUCCHI J. \& L. PENEV. 2018 (eds.), Species 2000 \& ITIS Catalogue of Life, 2018 Annual Checklist. DVD. Species 2000. Naturalis, Leiden.

ROSSI G., PAROLO G. \& T. ULIAN 2009. Human trampling as a threat factor for the conservation of peripheral plant populations. Plant Biosystematics 143: 104-113. https://doi.org/10.1080/11263500802633725

SALDANHA C.J. 1974. Smithsonia (Orchidaceae) a new genus from Western India.Journal of the Bombay Natural History Society 71: 70-75.

SARKAR A.K. 1995. Endemic genera of angiosperms and their species in India. In: GUPTA S.K. (ed.), Higher Plants of Indian Subcontinent. Volume 1. Indian Journal of Forestry Additional Series IV. Dehra Dun. pp. 235-257.

SASIDHARAN N. 2004. Biodiversity documentation for Kerala. Part 6: flowering plants. Kerala Forest Research Institute, Kerala.

SHAHINA P.M. \& S. NAMPY 2014. A taxonomic revision of the genus Canscora in South India, and the erection of the new genus Canscorinella (Canscorinae, Gentianaceae) with two new combinations. Phytotaxa 164: 201-225. https://doi.org/:10.11646/phytotaxa. 164.4.1

SHARMA B.V., KARTHIKEYAN S. \& N.P. SINGH (eds.) 1996. Flora of Maharashtra State (Dicotyledones). Volume 1. Botanical Survey of India, Kolkata.

SHAW A.H.K. 1952. A new genus and species of Burmanniaceae from South India. Kew Bulletin 2: 277-279.

SHIVAMURTHY G.R. \& K.B. SADANAND 1997. A new species of Willisia Warm. (Podostemaceae) from the Silent Valley of Kerala, India. Kew Bulletin 52: 243-245. https://doi.org/10.2307/4117861

SINGH P., DASH S.S. \& K. SANJAY 2018. Plant discoveries 2017. Botanical Survey of India, CGO Complex Salt Lake City, Kolkata.

SINGH N.P., KARTHIKEYAN S., LAKSHMI NARASIMHAN P. \& S.S. DASH 2015. Endemic vascular plants of India. Botanical Survey of India, Kolkata.

SINGH N.P., LAKSHMINARASIMHAN P., KARTHIKEYAN S. \& P.V. PRASANNA 2001. Flora of Maharashtra State: Dicotyledones. Volume 2. Botanical Survey of India, Kolkata.

SINGH D.K. \& P.K. PUSALKAR 2020. Floristic Diversity of the Indian Himalaya. In: DAR, G. \& A. KHUROO (eds.), Biodiversity of the Himalaya: Jammu and Kashmir State. Biodiversity and Conservation, Volume 18. Springer, Singapore.

SNMNH (Smithsonian National Museum of Natural History), 2011. A checklist of the trees, shrubs, herbs and climbers of Myanmar. Available at: http:// botany.si.edu/myanmar

SOHMER S.H. 1976. Studies in the Amaranthaceae: 1 . The genus Indobanalia. Phytologia 34: 235-239.

SOUZA E.R., KRISHNARAJ M.V. \& L.P. QUEIROZ 2016. Sanjappa, a new genus in the tribe Ingeae (Leguminosae: Mimosoideae) from India. Rheedea 26(1): $1-12$.

SREEKUMAR P.V. \& T. COOMAR 1999. Bentinckia nicobarica: an endemic, endangered palm of the Nicobar Islands. Palms 43: 118-121.

SREEKUMAR P.V.S. \& B.V. SHETTY 1987. Bhidea ûscheri, a new species of Gramineae from India. Kew Bulletin 42: 683-685. 
STUESSY T.F., DANIEL J.C., CLODOMIRO M. \& S.O. MARIO 1998. Isolation mechanisms and modes of speciation in endemic angiosperms of the Juan Fernandez Islands. In: STUESSY T.F. \& M. ONO (eds.), Evolution and speciation of island plants. Cambridge University Press, Cambridge. pp. 79-96.

TAKHTAJAN A. 1986. Floristic regions of the world. University of California Press, Berkeley.

TROPICOS 2020. Missouri Botanical Garden, Shaw Boulevard, St. Louis, Missouri. http://www. tropicos.org

UNIYAL B.P. 1995. Tribe 12. Vernonieae Cass. In: HAJRA, P.K., RAO, R.R., SINGH, D.K. \& B.P. UNIYAL (eds.), Flora of India. Volume 13. Botanical Survey of India, Kolkata.

UNIYAL B.P. \& D.C. PAL 1983. Additional locality for Chandrasekharania keralensis. Journal of Economic and Taxonomic Botany 4: 950.

VANDERPLANK S.E., A. MUNOZ C.H., PILS G.J.N., NOROOZI V.R.C., BARKER N.P., YANG W., HUANG J., MA K., TANG C.Q., WERGER M.J.A., OHSAWA M. \& Y. YANG 2014. Endemism in mainland regions - case studies. In: HOBOHM C. (ed.), Endemism in Vascular Plants. Springer Science, New York.
VENU P. 1998. A review of floristic diversity, inventory and monitoring methods in India. Proceedings of the Indian Academy of Sciences (Plant Sciences) 64: 281-292.

VENU P. 2006. Strobilanthes Blume (Acanthaceae) in Peninsular India. Botanical Survey of India, Kolkata.

VERON S., HAEVERMANS T., GOVAERTS R.M. \& R. PELLENS 2019. Distribution and relative age of endemism across islands worldwide. Science Report 9: 11693. https://doi.org/10.1038/s41598-019-47951-6

VOLIS S. 2019. Conservation-oriented restoration - a two for one method to restore both threatened species and their habitats. Plant Diversity 41(2): 50-58. https:// doi.org/10.1016/j.pld.2019.01.002

WILSON P.G. \& M.H. HESLEWOOD 2016. Phylogenetic position of Meteoromyrtus (Myrtaceae). Telopea 19: 45-55. https://doi.org/10.7751/telopea10389

YADAV S.R. \& M.M. SARDESAI 2002. Flora of Kolhapur District. Shivaji University, Kolhapur.

YOGANARASIMHAN S.N., RAO M.R. \& K.R.K. MURTHY 1997. Occurrence of Seshagiria sahyadrica Ansari \& Hemadri: an endemic Asclepiadaceae in Karnataka. Journal of Economic and Taxonomic Botany 21: 471-472. 